\title{
Nauczanie przyjazne mózgowi? Metody stosowane przez nauczycieli języka polskiego w gimnazjum wobec postulatów neurodydaktyki
}

\author{
Brain-friendly teaching? The methods used by the teachers \\ of the Polish language in a secondary school according \\ to neurodidactic demands
}

\author{
|| $\begin{aligned} & \text { Agnieszka Handzel } \\ & \text { Uniwersytet Jagielloński }\end{aligned}$
}

\begin{abstract}
This article presents opinions and postulates of neurodidactics, starting the change in education. The author, using parts of results of the research called "Dydaktyka literatury i języka polskiego w gimnazjum w świetle nowej podstawy programowej" (eng. "Polish language and literature didactics in a secondary school in the light of the new curriculum") considers the situation of Polish language education in a secondary school influenced by new research results connected with the efficiency of education.
\end{abstract}

Key words: neurodidactics, Polish language education, secondary school

Streszczenie: Artykuł przedstawia postulaty zmian w edukacji stawiane przez neurodydaktykę. Autor, korzystając z części wyników badania „Dydaktyka literatury i języka polskigo w gimnazjum w świetle nowej podstawy programowej”, podejmuje refleksję nad sytuacją dydaktyki polonistycznej w gimnazjum w świetle nowych doniesień badawczych związanych z efektywnością procesu kształcenia.

Słowa kluczowe: neurodydaktyka, edukacja polonistyczna, gimnazjum

\section{W poszukiwaniu nowych odpowiedzi}

Zmiany zachodzące we współczesnym społeczeństwie nie stanowią już zaskoczenia. W ciągu ostatnich kilku lat powstały dziesiątki opracowań analizujących wpływ „nowego świata” na różne aspekty życia ludzi. Naukowcy, badacze zjawisk społecznych, a wreszcie nauczyciele i rodzice, wszyscy poszukują odpowiedzi na pytania dotyczące podstawowych kwestii związanych $\mathrm{z}$ nauczaniem młodych ludzi w cyfrowej rzeczywistości. Stosowane dotychczas metody okazują się nieskuteczne w obliczu przemian w sposobach myślenia i uczenia się, jakie zaszły w ostatnim czasie. Badacze edukacji, poszukując rozwiązań wychodzących naprzeciw potrzebom dzisiejszych kilku- i kilkunastolatków, usiłują na nowo definiować teoretyczne podstawy procesu kształcenia. Nowe teorie edukacji, takie jak np. konektywizm, zdobywają zwolenników w wielu częściach świata. 
Poszukiwanie nowej drogi do skutecznej edukacji stało się wyzwaniem dla wszystkich, którym zależy na tym, by młode pokolenie wyposażyć w umiejętności konieczne do sprawnego funkcjonowania w społeczeństwie XXI w. W tym celu wybitni naukowcy podejmują trud łączenia różnorodnych perspektyw badawczych, co może dać odpowiedzi na pytania o przyszłość szeroko rozumianego procesu kształcenia.

Dynamiczny rozwój technologii wpływa na wszystkie dziedziny życia ludzi. Dzięki zminiaturyzowanym gadżetom i powszechnemu dostępowi do Internetu wszelkie informacje są na wyciągnięcie ręki. Cyfrowe nowinki wchodzą do naszych domów i szkół. Dzięki coraz doskonalszym technikom badawczym naukowcy mogą analizować wszelkie procesy zachodzące w naszych umysłach. Technika badania mózgu umożliwia dziś obserwację procesu uczenia się w czasie rzeczywistym; najmniejsze wysiłki podejmowane przez człowieka aktywują odpowiednie ośrodki w mózgu. Nowoczesny sprzęt pozwala badać zmiany zachodzące na poziomie pojedynczych synaps - podstawowych struktur neuronalnych. Z osiągnięć najnowszych badań nad mózgiem czerpie ciesząca się coraz większym uznaniem neurodydaktyka. Entuzjaści tej dyscypliny stawiają sobie za cel tworzenie nowych koncepcji pedagogicznych, które, opierając się na wynikach badań przeprowadzanych przez neurobiologów i neuropsychologów, pozwolą w pełni wykorzystać potencjał każdego człowieka (Żylińska 2013). ${ }^{1}$ Rzecz jasna, żadna z nowych teorii edukacji nie daje odpowiedzi na wszystkie nurtujące pedagogów i dydaktyków pytania. Nowo powstające koncepcje wykorzystują najnowsze osiągnięcia technologii i wyniki badań, nie sposób jednak ominąć wieloletniej tradycji badań nad edukacją, które wypracowały wiele dobrych praktyk. ${ }^{2}$ Trafnym wstępem do refleksji nad miejscem neurodydaktyki w kształtowaniu oblicza nowoczesnej edukacji jest twierdzenie Marka Kaczmarzyka³ ${ }^{3}$ propagatora koncepcji dydaktyki ewolucyjnej:

Najnowsze osiągnięcia neurobiologii otwierają nowe perspektywy, nowe krajobrazy interpretacyjne dla dydaktyków oraz nauczycieli i wychowawców. Rozpoznanie mechanizmów neurologicznych, nawet jeśli są one ściśle związane z procesami uczenia się i nauczania, nie gwarantuje jeszcze właściwego wykorzystania tej wiedzy w praktyce [podkr. AH]. Neurodydaktyka może się okazać obszarem takich właśnie poszukiwań i wraz z dydaktyką ewolucyjną tworzyć propozycje praktycznych rozwiązań (Kaczmarzyk, Kopeć 2012, 208).

\footnotetext{
Popularność neurodydaktyki rozpoczęła się po publikacji książki neurobiologa Manfreda Spitzera Jak uczy się mózg (2012), w której, przytaczając obszernie wyniki wieloletnich badań i eksperymentów neurobiologicznych, w przystępny sposób wyjaśnił procesy zachodzące w mózgu podczas zdobywania nowych umiejętności. Ważne dla rozwoju dyscypliny są również pozycje autorów takich jak: Gerald Huther, Gary Small, Joachim Bauer. W Polsce rozgłos medialny zyskała książka M. Żylińskiej Neurodydaktyka. Nauczanie i uczenie się przyjazne mózgowi (2012).

2 Przegląd współczesnej metodyki kształcenia opierającej się na wieloletnich doświadczeniach można znaleźć np. w podręczniku D. Biernackiej, 2001, Od słowa do działania. Przegląd współczesnych metod kształcenia, Warszawa.

3 M. Kaczmarzyk to redaktor naczelny internetowego czasopisma „Neurodydaktyka. Praktyka-BadaniaDialog"; więcej na temat dydaktyki ewolucyjnej, jej związków z neurodydaktyką, zob. Kaczmarzyk M., Kopeć D., 2012 .
} 
Wzrastająca popularność neurodydaktyki nie może umknąć uwadze osób bacznie obserwujących najnowsze tendencje kształtowania nowoczesnej edukacji. Mając w pamięci dokonania wcześniejszych pokoleń, warto wykorzystać „nowe krajobrazy interpretacyjne”, jakie otwierają się przed nami i poddać kolejnej krytycznej refleksji obowiązujący system kształcenia. Podstawowym założeniem neurodydaktyki jest teza, że uczenie się to naturalny proces, do którego stworzony został ludzki mózg. Neurodydaktycy twierdzą, że chęć poznawania świata i jego zrozumienia to organiczne potrzeby jednostki. Każde dziecko chce podążać za wrodzoną ciekawością poznawczą, a zadaniem szkoły jest stworzenie środowiska, które będzie sprzyjać jego poczynaniom. Zmiana, jaką postulują, polega na odejściu od tradycyjnej perspektywy opierającej się na obserwacji i ocenianiu efektów kształcenia (Żylińska 2013). Wnioski dotyczące efektywności stosowanych metod i zabiegów dydaktycznych należy wysnuwać na podstawie badania przebiegu samego procesu uczenia się. Wiąże się to ze zwróceniem bacznej uwagi na szkolną codzienność i odejściem od systemu opartego na analizie wyników końcowych egzaminów. Taka postawa ma sprzyjać kreowaniu środowiska „przyjaznego mózgowi”, zgodnie z angielską nazwą dyscypliny: brainbased learning, brainfriendly learning. Wykorzystanie $\mathrm{w}$ praktyce szkolnej propozycji stawianych przez naukowców analizujących najnowsze badania nad mózgiem może sprawić, że podejmowane przez nauczycieli wysiłki będą bardziej efektywne, a sama nauka stanie się dla uczniów przyjemnością.

Neurodydaktyka jest określana jako nauka interdyscyplinarna - łączy osiągnięcia z zakresu biologii, edukacji i psychologii. Wnioski wysnuwane przez jej przedstawicieli trafiają w potrzeby współczesnych uczniów, którzy borykają się z trudnościami w szkolnej codzienności. Nie ma jeszcze możliwości zweryfikowania pewnych twierdzeń stawianych na podstawie najnowszych wyników badania mózgu, ale wydaje się, że zgodność postulatów neurodydaktyków z ideami wielkich reformatorów edukacji takich, jak Maria Montessori czy Rudolf Steiner, stanowi niejako potwierdzenie ich słuszności. W wielu punktach nowa dyscyplina adaptuje również tezy zwolenników konstruktywistycznej teorii kształcenia. Marzena Żylińska, nauczycielka, wykładowca akademicki, od lat stosująca osiągnięcia neurodydaktyki w praktyce, twierdzi, że problem możliwości wykorzystania osiągnięć neuronauk w szkole jest podobny do sytuacji wprowadzania nowych procedur medycznych. W przypadku medycyny, po opracowaniu nowej koncepcji następuje faza testów i eksperymentów, które potwierdzają jej słuszność. Następnie nowe rozwiązanie wdraża się na szeroką skalę. Autorka książki Neurodydaktyka. Nauczanie i uczenie się przyjazne mózgowi apeluje o wprowadzenie podobnego sposobu działania do kształcenia (upraszczając nieco ten złożony przecież proces). W razie szkolnych niepowodzeń i problemów nauczyciel, zamiast szukać winy po stronie 
ucznia lub rodziców, powinien zadać sobie pytanie: „Może w tym przypadku inna metoda byłaby bardziej skuteczna?” (Żylińska 2013, 15).

Skupienie na tym, by wdrożyć osiągnięcia neuronauk do szkolnej praktyki w postaci zmiany metodyki nauczania, wiąże się z możliwością obserwacji efektów podejmowanych działań w postaci eksperymentów dydaktycznych. Pozwala również przyjąć odwrotną perspektywę analizując stosowane przez nauczycieli metody, można zastanowić się nad tym, na ile dzisiejsza szkoła jest „przyjazna mózgowi”. Neurodydaktycy twierdzą, że współczesny system edukacji nie pozwala uczniom w pełni rozwinąć swoich możliwości, wypowiedzi propagatorów tej perspektywy zdają się potępiać wszelkie panujące w szkole zasady i tendencje ${ }^{4}$. Analiza badań sprawdzających, jakich metod rzeczywiście używają najczęściej nauczyciele, z uwzględnieniem zaleceń neurodydaktycznych, może oznaczać nowe spojrzenie na sytuację polskiej szkoły i stać się punktem wyjścia do dyskusji o możliwości wprowadzenia zmian, które pozwolą w szerszym zakresie wykorzystać naturalną ciekawość poznawczą uczniów.

Warto jednak podkreślić, że wszelkie postulaty stawiane na podstawie wyników badań nad działaniem mózgu należy przyjmować z dużą dozą krytycyzmu. Niektórzy badacze, jak np. Marek Kaczmarzyk, podkreślają opisowy i diagnozujący charakter dyscypliny znanej jako neurodydaktyka. Taka rozbieżność (od konkretnych propozycji i rozwiązań metodycznych po ostrożne wnioski-obserwacje) wynika z faktu, iż aktualny stań badań nad działaniem mózgu nie pozwala stawiać niepodważalnych tez dotyczących wpływu czynników zewnętrznych i ewentualnych zmian metodycznych na wewnętrzne efekty procesu kształcenia ${ }^{5}$.

\section{Polonista w szkole XXI wieku}

Zmieniające się wymagania wobec absolwentów wkraczających na rynek pracy sprawiają, że nauczyciele stają przed trudnym zadaniem wyposażenia uczniów w kompetencje konieczne do prawidłowego funkcjonowania w dorosłym życiu, a wcześniej ich zdefiniowania. Howard Gardner, usiłując przewidzieć, jakie kompetencje będą najbardziej potrzebne społeczeństwom XXI w., sformułował teorię pięciu umysłów. Oznaczają one różne sposoby wykorzystania myślenia i rozumowania, które mogą być doskonalone przez szkołę. Umiejętności takie, jak samokształcenie, krytyczny odbiór informacji oraz ich syntetyczne wykorzystanie, kreatywność, szacunek wobec inności czy zdolność samokontroli zachowania pod względem etycznym, będą według niego najbardziej potrzebne wszystkim jednostkom w najbliższym czasie (Gardner 2009). Z tymi przewidywaniami wiąże się nowe spojrzenie na pracę nauczycieli. Nauczyciel polonista ma

\footnotetext{
4 Hasło promujące książkę Żylińskiej brzmi: „W przedwczorajszych szkołach wczorajsi nauczyciele uczą dzisiejszych uczniów rozwiązywania problemów jutra.”

Takie stanowisko przedstawia konsekwentnie Marek Kaczmarzyk, m. in, podczas warsztatów „Neurodydaktyka doktora Kaczmarzyka”, które odbyły się 21.11.2015 w CINiBA w Katowicach w ramach II Kongresu Dydaktyki Polonistycznej.
} 
szczególne predyspozycje do kształtowania nowych umiejętności przez kontakt z uniwersalnymi wartościami obecnymi w literaturze, możliwość wprowadzania na lekcje nowych technologii czy wzmacniania naturalnej kreatywności uczniów. Nie bez znaczenia jest również fakt, że organizacja systemu szkolnego wymaga, by to właśnie polonista spędzał z uczniami bardzo dużo czasu. Jego zachowanie, postawa, umiejętność stworzenia w klasie przyjaznej atmosfery i nawiązania bliskiej relacji z uczniami również mają ogromny wpływ na ich osiągnięcia, dlatego analiza stosowanych przez nauczycieli polonistów metod nauczania jest tak istotna w obserwacji przebiegu całego procesu kształcenia, o którą apelują neurodydaktycy.

Na początku 2013 r., w ramach projektu badawczego „Dydaktyka literatury i języka polskiego $\mathrm{w}$ gimnazjum $\mathrm{w}$ świetle nowej podstawy programowej", odbyły się badania ilościowe. Przeprowadzenie kompleksowej diagnozy stanu dydaktyki polonistycznej zlecił Instytut Badań Edukacyjnych, realizujący projekt systemowy „Badanie jakości i efektywności edukacji oraz instytucjonalizacja zaplecza badawczego". W badaniach terenowych uczestniczyły zespoły badawcze z różnych regionów kraju, w tym z Wydziału Polonistyki Uniwersytetu Jagiellońskiego ${ }^{6}$.

Statystycznie reprezentatywną grupę badawczą stanowili uczniowie, rodzice uczniów, nauczyciele poloniści, bibliotekarze oraz dyrektorzy z 60 gimnazjów w pięciu województwach. Reprezentatywna grupa uczniów z tych szkół w ostatnich miesiącach 2012 r. poddana została badaniom jakościowym. Dobór grupy badawczej miał charakter warstwowy i przebiegał dwustopniowo: wylosowano szkoły, a następnie po dwa oddziały z każdej klasy (I-III). Celem badań była diagnoza stanu nauczania języka polskiego na III etapie edukacji, jak również zidentyfikowanie czynników, które różnicują uczniów w zakresie wiedzy i umiejętności. Badania jakościowe polegały na przeprowadzeniu indywidualnych wywiadów pogłębionych oraz zogniskowanych wywiadów grupowych z uczniami i nauczycielami, obserwacji uczestniczącej i rejestracji lekcji języka polskiego, analizie dokumentów szkolnych, materiałów internetowych oraz projektu internetowego WebQuest, w którym uczestniczyli uczniowie. W ramach badań ilościowych uczniowie wypełnili trzy testy wiedzy i umiejętności oraz kwestionariusz ankiety $\mathrm{w}$ warunkach zbliżonych do egzaminacyjnych. Rodzice wypełnili kwestionariusz ankiety, a nauczyciele i dyrektorzy ankietę on-line. W analizie statystycznej wykorzystano ankiety 163 nauczycieli polonistów i 5228 uczniów. W ankietach dla nauczycieli znalazło się pytanie o najczęściej stosowane metody, techniki i formy pracy. Uczniowie odpowiedzieli na pytanie o częstotliwość wykonywanych na lekcjach czynności. Dodatkowe wnioski płyną z analizy materiału zebranego podczas badań jakościowych. W niniejszym opracowaniu wykorzystano

6 Autorka była w latach 2012-2014 członkiem zespołu badawczego składającego się z pracowników i doktorantów KPEN WP UJ. Była również autorką powstających w ramach projektu narzędzi dydaktycznych dla III etapu edukacji polonistycznej. 
wypowiedzi uczniów i nauczycieli zebrane podczas wywiadów indywidualnych i grupowych oraz materiał z badań ilościowych - odpowiedzi, które znalazły się w ankietach.

\section{Otworzyć się na uczniów}

Najsilniej akcentowanym postulatem neurodydaktyki jest odejście od tradycyjnego - transmisyjnego modelu nauczania, w którym nauczyciel „przekazuje” uczniom wiedzę w formie wykładów. Przyczyną takiego podejścia jest analiza przebiegu procesu uczenia się pod względem reakcji struktur nerwowych. Neurodydaktyka zwraca uwagę na fakt, że ogromna ilość bodźców docierająca w każdej chwili do ludzkiego mózgu wymusza przeprowadzenie procesu selekcji na samym początku przyswajania nowych informacji. Decyzja o tym, które informacje zostaną zapamiętane, zapada częściowo podświadomie. Umysł, dzieląc informacje na przydatne i nieprzydatne, kieruje się subiektywnymi kategoriami korzyści; pyta „Czy to jest dla mnie istotne?”. Tylko informacje sklasyfikowane jako ważne, nowe, zaskakujące przyciągają uwagę na tyle, by trafić do głębszych struktur pamięci. Ogromną rolę w przyswajaniu nowej wiedzy odgrywa również dotychczas posiadany zasób informacji i doświadczeń. Zapamiętywanie polega (w uproszczeniu) na powiązaniu nowych informacji z już posiadanymi, wobec tego, jeśli uczniowie nie mają odpowiedniego „zaplecza”, nie będą w stanie prawidłowo ocenić przydatności nowych informacji, a następnie przyswoić ich. Spitzer zauważa:

Ważne jest, by sobie uzmysłowić, że już samo mówienie o przekazywaniu - może nawet wartości - całkowicie rozmija się z rzeczywistością uczenia się. Mózgom niczego się nie przekazuje. One wytwarzają to samodzielnie! (Spitzer 2012, 288)

Warunkiem koniecznym do prawidłowego przebiegu tak rozumianego procesu uczenia się jest indywidualna, podejmowana z własnej woli, aktywność każdego ucznia. Uczeń ma stać się podmiotem procesu kształcenia, w związku z tym metody stosowane przez nauczycieli powinny wyzwalać i umożliwiać podejmowanie samodzielnych działań. Podstawowym zadaniem nauczyciela staje się zatem nawiązanie z uczniem odpowiedniej relacji, która stanowi najważniejszy element szeroko rozumianego „przyjaznego środowiska" edukacyjnego. Potwierdzenie postulatu dotyczącego budowania silnej więzi i skutecznej komunikacji między nauczycielem i uczniami można znaleźć w wypowiedziach badanych gimnazjalistów. Projektując model idealnej lekcji, uczniowie podkreślali przede wszystkim rolę otwartej rozmowy, będącej w ich opinii elementem koniecznym „dobrej lekcji”. Młodzi ludzie chcą, by na lekcjach poruszane były tematy bliskie ich zainteresowaniom, ich życiu. Stopień relacji oraz jakość komunikacji z nauczycielem są również czynnikami warunkującymi postrzeganie dotychczasowych lekcji. Uczniowie podkreślają wagę wartościowej komunikacji, która daje im poczucie bezpieczeństwa i akceptacji, motywuje do pracy. Jedną z cech 
idealnego nauczyciela, powtarzających się w wypowiedziach uczniów, jest niestwarzanie sztucznego dystansu. Uczniowie cenią również otwartość i chęć do rozmowy, co potwierdzają ich wypowiedzi (podczas rozmowy o idealnej lekcji języka polskiego):

Dla mnie byłaby taka idealna, gdyby była dyskusja, taka żywa, taka na jakiś fajny, dynamiczny temat, a nie taka o jakiś, co podmiot liryczny miał na myśli w tym wierszu... dlaczego tak, a nie inaczej. No bo skąd my możemy wiedzieć, co ten człowiek miał na myśli pisząc to sto lat temu.

Albo po prostu, żeby było tak, żeby była taka luźna atmosfera po prostu. Żeby można było dużo podyskutować, a pani, żeby pilnowała, żeby nie było za głośno, ale żeby nie przyczepiała się, że tak naprawdę rozmawiamyº.

Te opinie gimnazjalistów są zgodne z twierdzeniami neurodydaktyków o silnym powiązaniu efektywności procesu kształcenia z relacjami panującymi w klasie. Niemiecki neurobiolog Gerhardt Huther postuluje zmianę postrzegania procesu uczenia się. Wyniki najnowszych badań wskazują na to, że jest to proces kognitywno-afektywny, a nie, jak dotychczas uważano, czysto kognitywny. Pozytywne emocje i poczucie akceptacji kojarzone z konkretnymi elementami nauki mogą w znacznym stopniu usprawnić jej przebieg przez wzmocnienie motywacji. Wówczas podjęcie aktywności stanie się aktem woli, co dodatkowo wpłynie korzystnie na wyniki osiągane przez uczącego się (Żylińska 2013).

\section{„Pomóż mi zrobić to samemu”}

Zdanie, będące wyrazem koncepcji nauczania Marii Montessori, pokazuje wyraźnie cel, do jakiego zmierzali reformatorzy edukacji. Dzisiejszy stan badań nad przebiegiem procesu uczenia się potwierdza intuicyjne przewidywania formułowane już przez Jeana Piageta, a zawierające się w często przytaczanym przez Marzenę Żylińską stwierdzeniu: Wszystko, co robimy dla lub za ucznia, pozbawia go możliwości zrobienia tego samemu. W tych słowach kryje się, oczywisty dla większości nauczycieli, apel o aktywizowanie uczniów do samodzielnej pracy, czynnego udziału w rozwiązywaniu problemów i przetwarzaniu informacji. Żylińska zwraca uwagę na rolę podręczników i zeszytów ćwiczeń w dzisiejszej szkole. Stworzone przez specjalistów, posiadające określoną strukturę i układ treści materiały nie zawsze skłaniają ucznia do rzeczywistej aktywności intelektualnej. Wypełnianie wielokrotnie podobnych ćwiczeń, bez aktywnego przetwarzania związanej z nimi wiedzy, nie przyczynia się do poprawy efektów uczenia się. Z punktu widzenia neurodydaktyki, byłoby dużo lepiej, gdyby uczeń samodzielnie opracowywał materiały, kategoryzował i porządkował zawartą w nich wiedzę. Takie czynności są, według neurodydaktyków, najprostszą drogą do

\footnotetext{
Wszystkie cytaty z wypowiedzi uczniów pochodzą z ankiet i transkrypcji wywiadów będących częścią badania jakościowego projektu badawczego „Dydaktyka literatury i języka polskiego w świetle nowej podstawy programowej”. Dane statystyczne przytaczane w tekście głównym pochodzą z raportu końcowego po tym badaniu.
} 
nabycia przez uczniów pożądanych umiejętności związanych ze zdobywaniem i przetwarzaniem informacji oraz przyswajaniem nowej wiedzy. Z tym postulatem wiąże się również konieczność zmiany formy notatki szkolnej. Jeżeli uczniowie nauczą się poprawnie notować samodzielnie, samo zapisywanie notatek pomoże im w zapamiętywaniu nowych informacji (Żylińska 2013).

Tymczasem, jak wskazują wyniki badań, do najczęściej wykonywanych na lekcjach języka polskiego czynności należy zapisywanie $\mathrm{w}$ zeszycie przedmiotowym notatki dyktowanej przez nauczyciela. 3/4 polonistów szacuje, że dyktują notatki przynajmniej raz w tygodniu. Podczas obserwowanych lekcji blisko połowa zapisanych notatek została podyktowana przez nauczyciela. Taka forma aktywności nie pozwala uczniom rozwijać nowych umiejętności, sprzyja mechanicznemu uczeniu się zapisanych treści na pamięć bez głębszej refleksji, co w efekcie prowadzi do powstania zasobów tzw. „martwej wiedzy”, która najprawdopodobniej w niedługim czasie zostanie wymazana z pamięci. Uczniowie niepotrafiący sporządzić samodzielnie dobrej notatki mogą mieć problemy z samodzielnym uczeniem się, co jest niepokojącym zjawisko w czasach, gdy samokształcenie stanowi jedną z umiejętności kluczowych. Dodatkowo, co potwierdzają wypowiedzi gimnazjalistów, dyktowanie notatki sprawia, że uczniowie czują się mniej komfortowo:

To dyktowanie jest... „A wiecie, co to jest reportaż”- tak mówi. „Według mojej definicji... teraz to zapiszcie”. Nie może być swoimi słowami, tylko musi być dokładnie tak samo. A przecież my wiemy, co to jest reportaż!

Pani wyjmuje swoje kartki, tam ma... sprawdza po kolei czy wszyscy.... Traktuje nas jak dzieci, które nie umieją sobie same czegoś zapisać.

Neurodydaktycy apelują o wprowadzanie na lekcje metod aktywizujących, które mają pomóc uczniom w przetwarzaniu nowo nabytej wiedzy oraz zwiększyć ich motywację. Nauczyciele poloniści chętnie po nie sięgają, co sprzyja nawiązywaniu dobrych relacji z uczniami. Do najczęściej wykorzystywanych przez badanych polonistów metod aktywizujacych należą: głośne czytanie przez uczniów (również z podziałem na role), burza mózgów oraz indywidualne arkusze pracy. Nauczyciele deklarują także, że prowokują uczniów do żywych dyskusji przez stawianie kontrowersyjnych pytań, poruszanie tematów interesujących dla młodych ludzi, chętnie też decydują się na swobodną rozmowę podczas omawiania dzieł literackich. Widać więc wyraźnie, że poloniści najbardziej cenią metody wymagające komunikacji między uczniem i nauczycielem. Zachęta do rozmowy na różnorodne tematy stanowi ważny czynnik motywujący, a poruszanie treści istotnych dla młodych ludzi budzi w nich chęć samodzielnego podjęcia dalszych działań. Badania wskazują również na zależność między „swobodną rozmową o dziele literackim” a konkretnymi umiejętnościami 
uczniów. Obecność tej formy pracy na większości lekcji pozytywnie wpływa zarówno na kompetencje z zakresu analizy i interpretacji tekstów kulturowych, jak i językowe.

Zastanawia jednak fakt, że nauczyciele mniej chętnie decydują się na wykorzystanie metod wymagających „odkrzesłowienia” uczniów; dwie trzecie grupy pytanych polonistów deklaruje, że nigdy lub prawie nigdy nie wykorzystuje w swojej pracy happeningu, zaś metody projektu nie stosuje blisko jedna piąta badanych. Metody takie, jak dyskusja panelowa, metoda przypadków, gorące krzesło czy kapelusze myślowe również nie cieszą się popularnością wśród badanych. To wyraźnie ilustruje stosunek nauczycieli do procesu uczenia się: dominuje tradycyjne podejście, w którym uczniowie siedzą w ławkach i pracują pod kierunkiem prowadzącego zajęcia. Odmienna aranżacja przestrzeni, dopuszczenie „rozluźnienia” dyscypliny, mogłyby pozytywnie wpłynąć na aktywność uczniów i ich zainteresowanie przedmiotem.

\section{Neuronalne lustro, czyli towarzyski mózg}

W 2010 r. odkryto w ludzkim mózgu nowe struktury neuronalne mające związek również z procesem uczenia się. Odkryte przez amerykańskich badaczy neurony lustrzane uaktywniały się, gdy badana osoba wykonywała jakąś czynność lub obserwowała jej wykonywanie. Pozostawały jednak nieaktywne, gdy badanemu pokazywano zapisaną nazwę tej samej czynności (Żylińska 2013). Na podstawie podobnych eksperymentów neurolodzy wysnuli wniosek, że nowo odkryte struktury odpowiadają przede wszystkim za możliwość współodczuwania oraz identyfikowania uczuć obserwowanych innych osób. Kolejne badania pokazują jednak, że neurony lustrzane w dużej mierze są związane z procesem uczenia się. Dzięki nim zachodzą znane już od wielu lat procesy odzwierciedlenia i współbrzmienia, najistotniejsze dla prawidłowej socjalizacji i przenoszenia doświadczenia z pokolenia na pokolenie. Neurony lustrzane pozwalają dziecku prawidłowo interpretować zachowania innych ludzi i nawiązywać więzi. Co istotne, uczą się jedynie pod wpływem faktycznej aktywności, nie reagują na przekaz werbalny. Najistotniejsze znaczenie dla ich działania mają prawidłowe relacje uczącej się jednostki z otoczeniem oraz możliwość obserwowania wzorców pożądanych zachowań. By zapewnić prawidłowy rozwój tych aspektów osobowości, za które odpowiadają neurony lustrzane, neurodydaktycy postulują „odkrzesłowienie” edukacji - umożliwienie uczniom jak najczęstszego obserwowania różnorodnych zjawisk w rzeczywistości oraz wchodzenia w różne role. Dziecko, stając się na chwilę kimś innym, musi wczuć się w jego emocje i przeanalizować ewentualne formy zachowania. Takie doświadczenie głęboko zapada w pamięć i pozwala w znacznej mierze rozwinąć empatię oraz skuteczniej nabywać nowe umiejętności. Konieczność współpracy z innym dodatkowo zwiększa szanse na 
podniesienie efektywności procesu uczenia się przez możliwość obserwacji reakcji i zachowań współpracujących osób.

Wobec takiego postulatu tradycyjne metody nauczania wydają się zupełnie bezużyteczne. Okazuje się jednak, że poloniści bardzo chętnie sięgają po pracę w grupach. Co ciekawe, w opinii nauczycieli praca w grupach staje się pełnoprawną metodą nauczania, a ponad jedna trzecia deklaruje jej stosowanie co najmniej raz w tygodniu. Tę formę organizacji pracy zaobserwowano na ponad połowie lekcji obserwowanych w badanych szkołach. Z badań wynika, że nauczyciele często stosują metody kształtujące umiejętność współpracy i wymagające od uczniów wspólnego działania. Nie przeszkadza im wynikające z takiej organizacji lekcji chwilowe „rozluźnienie dyscypliny” lub gwar panujący wówczas w klasie. Również uczniowie pozytywnie oceniają pracę w grupach, wskazując na możliwość wykazania się przez wszystkich oraz podkreślając wagę możliwości wspólnego wypracowania odpowiedzi lub rozwiązania problemu.

Możliwość przyjmowania przez uczniów różnych perspektyw, wchodzenia w role, daje metoda dramy. Wydawać by się mogło, że nauczyciele poloniści, ze względu na charakter przedmiotu, sięgają po taką formę pracy raczej chętnie. Wyniki badań wskazują jednak, że drama jest jedną z najrzadziej wykorzystywanych metod - pojawiła się na zaledwie kilku z obserwowanych lekcji, a blisko jedna trzecia nauczycieli deklaruje, że nie stosuje tej metody w ogóle lub prawie nigdy. Co ciekawe, nauczyciele, którzy wykorzystują dramę na swoich lekcjach, są bardzo zadowoleni z takiej formy aktywności. Wydaje się zatem, że niestosowanie metod dramowych wynika raczej z czynników niezwiązanych bezpośrednio z atrakcyjnością lub skutecznością samej metody. Można podejrzewać, że nauczyciele nie w pełni ufają uczniom - obawiają się, że ci nie sprostają zadaniu wcielenia się w role lub postrzegają tę formę pracy jako trudną ze względu na chwilowy chaos, jaki wprowadza. Możliwe również, że w dążeniu do realizacji programu nauczyciele preferują metody dające efekty możliwe do zweryfikowania za pomocą testów czy sprawdzianów. W obliczu wywołanej zmianami społecznymi konieczności doskonalenia u uczniów przede wszystkim kompetencji miękkich, związanych z umiejętnością współpracy czy kreatywnością, takie podejście może przynieść negatywne skutki. Należy jednak wziąć pod uwagę fakt, że system testów kompetencji doprowadził do sytuacji, w której to przez pryzmat wyników, jakie osiągają uczniowie, oceniana jest praca nauczyciela.

\section{Uczyć się wszystkimi zmysłami}

Wpływ jakości otoczenia oraz ilości docierających do mózgu bodźców na proces uczenia się jest niewątpliwy. Wszystkie zmysły, odbierając informacje ze świata, uczestniczą w procesie uczenia się. Neurodydaktycy podkreślają, że ewolucja naszego gatunku znacznie przyspieszyła, gdy nasi 
przodkowie zaczęli wykorzystywać zaawansowane narzędzia. Postępujący rozwój aktywności umysłowej jest nierozerwalnie związany z wykorzystaniem wszystkich zmysłów. Wykonywanie czynności wymagających precyzji manualnej wpływa na mózg równie korzystnie jak słuchanie muzyki i śpiew. Uogólnienie tego twierdzenia prowadzi do wniosku, że im więcej zmysłów uczestniczy w procesie uczenia się, tym lepsze przyniesie on efekty. Tworzenie bogatego środowiska, w którym występują różnorodne bodźce odbierane przez wszystkie zmysły, może prowadzić do poprawy warunków rozwoju sieci neuronalnej (Żylińska 2013) ${ }^{8}$. Pierwszym i podstawowym środowiskiem uczenia się jest dla każdego dziecka dom rodzinny, dlatego tak ważna jest świadomość rodziców w kwestii potrzeb młodego umysłu dotyczących dostarczania odpowiedniej ilości różnorodnych bodźców. Uczniowie spędzają jednak w szkole niemal tyle samo czasu, co w domu, zatem to zadaniem nauczycieli staje się stworzenie odpowiednich warunków sprzyjających rozwojowi młodych umysłów.

W świecie zdominowanym przez nowe technologie nie sposób pominąć kwestii ich obecności na lekcjach języka polskiego. Powszechny dostęp do multimediów stanowi znaczne ułatwienie dla nauczycieli dążących do stworzenia środowiska przyjaznego nauce z wykorzystaniem wszystkich zmysłów. Również specyfika przedmiotu i jego otwartość na różnorodne konteksty sprawia, że nauczyciel polonista powinien jak najczęściej sięgać po różnorodne formy przekazu aktywizujące wszystkie zmysły uczniów. Badania wskazują, że nauczyciele najchętniej sięgają po przekaz audiowizualny - dzięki dostępności narzędzi do odtwarzania filmów i muzyki mogą urozmaicać swoje lekcje, otwierając konteksty muzyczne i filmowe. Niepokoi jednak stosunkowo niewielka popularność multimedialnych narzędzi dydaktycznych na lekcjach języka polskiego. Prezentacja multimedialna to doskonała okazja, by połączyć wszystkie dostępne formy przekazu z ogromnymi zasobami treści dostępnych w Internecie. Stosunkowo niewielkim nakładem pracy można dzięki prezentacji pobudzić aktywność uczniów przez zainteresowanie ich tematem (i samą formą) oraz postawienie przed nimi ciekawych wyzwań, dzięki którym zdobyta wiedza zostanie poddana głębokiemu przetworzeniu. Nauczyciele jednak niechętnie wykorzystują prezentacje na swoich lekcjach - blisko jedna trzecia ankietowanych stwierdziła, że unika tej formy pracy. Prezentacje multimedialne wykonane przez uczniów również należą do aktywności najrzadziej pojawiających się na obserwowanych lekcjach. Tymczasem zaangażowanie uczniów w projekt, którego prezentacja odbędzie się właśnie z wykorzystaniem nowych technologii, może stanowić doskonałą okazję do pogłębienia omawianego zagadnienia i dać im możliwość samodzielnej pracy w atrakcyjnej formie. Niestety, poza obowiązkowym gimnazjalnym projektem edukacyjnym

\footnotetext{
8 Nawet jeżeli zależność między bogatym w bodźce środowiskiem, a rozwojem sieci neuronalnej nie jest tak prosta, jak przedstawia to Żylińska, to obserwacja uczniów dowodzi, że zapewnienie młodemu umysłowi odpowiednich warunków wszechstronnego rozwoju pozytywnie wpływa na jego późniejsze osiągnięcia.
} 
(w którego koordynację rzadko się poloniści włączają), nauczyciele języka polskiego niechętnie sięgają również po metodę projektu na swoich zajęciach, chociaż ponad połowa z nich deklaruje, że wykorzystuje ją kilka razy w roku. Podczas analizy zależności wykorzystywanych przez nauczyciela metod z wynikami z testów kompetencji, które wypełnili badani uczniowie, okazało się, że im częściej nauczyciele wykorzystują prezentacje komputerowe na zajęciach, tym lepsze wyniki osiągają ich uczniowie w zakresie analizy i interpretacji tekstów kultury. Badania wskazują również, że po multimedialne techniki częściej i chętniej sięgają nauczyciele w młodszym wieku, z mniejszym stażem pracy. W związku z tym nieobecność prezentacji na lekcjach języka polskiego należałoby powiązać ze średnią wieku aktywnych zawodowo polonistów. Nie można jednak uznać za normę tego, że tylko młodzi nauczyciele wykorzystują multimedia. Ogromny wachlarz możliwości, jakie stawia przed uczącymi rozwój nowych technologii, sprawia, że każdy zainteresowany wszechstronnym rozwojem uczniów nauczyciel powinien wykorzystywać nowe rozwiązania.

\section{Zaprzyjaźnić się z mózgiem}

Neurodydaktyka, jako dyscyplina naukowa, ciągle się rozwija. Kolejne badania nad zachodzącymi podczas uczenia się zmianami w mózgu przynoszą nowe wnioski i płynące $\mathrm{z}$ ich analizy postulaty dla edukacji. W poszukiwaniu odpowiedzi na pytania dotyczące słuszności postulowanych zmian należałoby prowadzić długoterminowe eksperymenty pedagogiczne. Warto jednak zastanowić się nad wprowadzeniem pewnych elementów nowego podejścia dydaktycznego do praktyki szkolnej. Ich słuszność potwierdzają intuicyjne postulaty reformatorów edukacji oraz badania prowadzone współcześnie.

Bliższa analiza propozycji przytoczonych w niniejszym artykule doprowadzić powinna do dwóch najważniejszych wniosków. Przede wszystkim, neurodydaktyka nie odkrywa właściwie żadnych nowych obszarów działania dla metodyki nauczania. W dokładniejszy sposób diagnozuje i opisuje to, co dzieje się z uczniami podczas nauki. Podobne postulaty (np. konieczności motywowania do nauki, nauczania polisensorycznego, włączania uczniów w decydowanie o procesie nauczania) formułowali w ciągu ostatnich dekad: Maria Montessori, Zenon Klemensiewicz czy Stanisław Bortnowski. Ich intuicje potwierdzało dydaktyczne doświadczenie, a osiągane efekty i popularność stosowanych metod do dziś świadczą o ich skuteczności. Drugą ważną kwestią jest - potwierdzona badaniami - świadomość, że nauczyciele niejako intuicyjnie wybierają to, co dla uczniów najlepsze. Przedstawione wyniki badań nad częstotliwością stosowania niektórych metod pracy prowadzą do wniosku, że nauczyciele samodzielnie podążają niejako $\mathrm{w}$ kierunku zmian postulowanych przez neurodydaktyków. Uczniowie zaś podkreślają wagę takich kwestii, jak skuteczna 
komunikacja czy przyjazna atmosfera i życzliwe nastawienie nauczyciela. Stan badań nad zmianami zachodzącymi w mózgu podczas uczenia się nie pozwala jeszcze na stawianie niepodważalnych tez, z czego zdają sobie sprawę neurodydaktycy. Należy zatem z dużą dozą krytycyzmu i ostrożnie podchodzić do promowanych „idealnych rozwiązań” opierających się na nie do końca zweryfikowanych przesłankach. Nie ma możliwości wprowadzenia rozwiązań systemowych, które pogodziłyby konieczność mierzenia osiągnięć uczniów i powszechnej edukacji z postulatami o nauczaniu „przyjaznym mózgowi” w ich pełnym zakresie. Warto jednak zwiększać świadomość nauczycieli w zakresie najnowszych osiągnięć dziedzin naukowych, które szukają dobrych rozwiązań dla edukacji, ponieważ może to prowadzić do refleksji nad ich własnym warsztatem, a przez to do pozytywnych zmian w szkolnej codzienności.

\section{Literatura:}

Biedrzycki Krzysztof, Bordzoł Piotr, Hącia Agata, Kozak Wioletta, Przybylski Błażej, Strawa Ewelina, Wróbel Iwona, 2015, Dydaktyka literatury i języka polskiego $w$ gimnazjum $w$ świetle nowej podstawy programowej. http://eduentuzjasci.pl/images/stories/publikacje/IBE-EE-raport-Dydaktykaliteratury-i-jezyka-polskiego.pdf (dostęp: 30.11.2015)

Gardner Howard, 2009, Pięć umysłów przyszłości, przeł. Bakalarz D., Warszawa.

Kaczmarzyk Marek, Kopeć Dorota, 2012, Ewolucja biologiczna a procesy uczenia się i nauczania. Dydaktyka ewolucyjna, w: Mazurkiewicz G. (red.), Jakość edukacji. Różnorodne perspektywy, Kraków, s. 203-214.

Spitzer Manfred, 2012, Jak uczy się mózg?, Guzowska-Dąbrowska M. (przeł.), Warszawa.

Żylińska Marzena, 2013, Neurodydaktyka. Nauczanie i uczenie się przyjazne mózgowi, Torun.

\section{O Autorce:}

Agnieszka Handzel - doktorantka w Katedrze Polonistycznej Edukacji Nauczycielskiej na Wydziale Polonistyki Uniwersytetu Jagiellońskiego, nauczycielka języka polskiego w Szkole Podstawowej w Kobielniku (woj. małopolskie). W latach 2012-2014 członek zespołu badawczego projektu Dydaktyka literatury i języka polskiego $w$ gimnazjum w świetle nowej podstawy programowej, w latach 2014-2015 członek zespołu badawczego projektu Akademickie Centrum Kreatywności na WP UJ, autorka i współautorka publikacji związanych z edukacją polonistyczną, (m. in. Nowe technologie na lekcjach języka polskiego, „Postscriptum Polonistyczne” 2014(2); Trudne lekcje języka polskiego, Kraków 2015). Zainteresowania badawcze autorki skupiają się wokół zastosowania nowych technologii w kształtowaniu kompetencji kluczowych (m. in. operowanie informacją, samokształcenie) w edukacji polonistycznej, nowoczesnych teorii edukacji i metod kształcenia kulturowego i językowego. 
